\section{Micropropagation of a Mature, Male Kentucky Coffeetree}

\author{
M.A.L. Smith and A.A. Obeidy \\ Department of Horticulture, University of Illinois, Urbana, \\ IL 61801-4720
}

Additional index words. clonal propagation, Gymnocladus dioicus, in vitro, morphogenesis, regeneration, tissue culture

Kentucky coffeetree [Gymnocladus dioicus L. (Leguminosae)] is a lofty, dioecious shade tree with considerable landscape merit. Female trees produce persistent, purple-brown pods that are 20 to $30 \mathrm{~cm}$ long, abscise erratically throughout the winter, and can detract from the landscape value of the species. However, since vegetative propagation of Kentucky coffeetree has been largely unsuccessful (Dirr and Heuser, 1987), male clones are not commercially available. In vitro shoot initiation has recently been accomplished from explants of seedlings and mature trees (Geneve et al., 1990), but we found no reports of procedures for complete micropropagation, including shoot elongation and rooting.

When a 21-m-tall male specimen growing on the Univ. of Illinois campus, with a diameter at breast height of $97 \mathrm{~cm}$, was partially destroyed by lightning, expanding 1year-old terminal shoots and watersprouts were collected in early spring to preserve this genotype by in vitro propagation. Axillary bud and shoot tip explants were washed in a mild detergent solution, then agitated for 20 min in $1.0 \% \mathrm{NaOCl}$ with $0.1 \%$ Tween 20 (polyoxyethylene sorbitan monolaurate; Sigma, St. Louis), and rinsed three times in sterile distilled water. Explants were cultured at $25 \pm 2 \mathrm{C}$ under a continuous photosynthetic photon flux (PPF) of 45 $\mu \mathrm{mol} \cdot \mathrm{m}^{-2} \cdot \mathrm{s}^{-1}$ provided by cool-white fluorescent lamps, in GA7 vessels (Magenta Corp., Chicago) containing $30 \mathrm{ml}$ of a modified MS medium (Murashige and Skoog, 1962) with $3 \%$ sucrose, $50 \mathrm{mg}$ ascorbic acid/ liter, a vitamin mixture, $0.7 \%$ agar, and either $0,0.1,1.0$, or $10 \mu M N-$ (phenylmethyl)- $1 \mathrm{H}$ purind-amine (BA) or $0,5,15$, or $25 \mu \mathrm{M}$ N-phenyl-N-'-1,2,3-thidiazol-5-ylurea (TDZ). At least 20 watersprout bud explants and 25 terminal shoot bud explants were cultured in each treatment. Only explants cultured with $\mathrm{BA}$ at 0.1 or $1.0 \mu \mathrm{M}$ survived beyond three subcultures at 30-day intervals, and produced limited green, nodular growth. About $80 \%$ of the explants derived from watersprouts and only $15 \%$ of the explants from terminal shoots of these media were suc-

Received for publication 19 Feb. 1991. We sincerely appreciate the efforts of Univ. of Illinois Horticulturist James E. Smith, who collected explanting material from the original specimen tree. The cost of publishing this paper was defrayed in part by the payment of page charges. Under postal regulations, this paper therefore must be hereby marked advertisement solely to indicate this fact. cessfully established in vitro and continued to produce new growth.

Multiple shoot buds were induced after subculture to a medium with $36 \mu \mathrm{M} \mathrm{BA}$ and $5 \mu \mathrm{M} 1 \mathrm{H}$-indole-3-butyric acid (IBA). Continuous culture on this medium produced highly regenerative nodular tissue that produced an average of 35 adventitious buds per month from each $0.5-$ to $1.0-\mathrm{cm}^{3}$ initial clump (Fig. 1). Division and proliferation of nodules were continuously achieved by monthly subculture. Shoot elongation at a rate of 3 $\mathrm{cm} \cdot \mathrm{month}^{-1}$ did not occur until transfer of the nodular tissue to a medium with $9.0 \mu \mathrm{M}$ BA and $0.5 \mu \mathrm{M}$ 1-naphthaleneacetic acid (NAA).

Shoots 3 to $6 \mathrm{~cm}$ long were transferred to a half-strength MS salts medium with $1.5 \%$ sucrose and 7.5 $\mu \mathrm{M}$ IBA. Cultures were held 1 week in darkness at $25 \pm 2 \mathrm{C}$, then exposed to light as above. Roots began to emerge after 3 weeks, with typically only one or two unbranched adventitious roots produced in vitro on each shoot (Fig. 2). Roots on individual microcuttings initially appeared between 3 to 12 weeks after transfer of microcuttings to rooting medium, with highest rooting frequency (root emergence/ time) after 7 weeks of culture (Fig. 3). Overall rooting efficiency was $22 \%$ after 12 weeks.

Rooted microcuttings were transplanted into a growing medium of 1 peat : 1 sand $(\mathrm{v} / \mathrm{v})$ and kept in an illuminated growth room under high humidity. In the growth room, continuous light was supplied by cool-white fluorescent lamps with a PPF of 40 to 50 $\mu \mathrm{mol} \cdot \mathrm{m}^{-2} \cdot \mathrm{s}^{-1}$ at the top of the canopy, with day/night temperature of $28 \pm 1 \mathrm{C}$. Relative humidity was maintained at $95 \%$ to $100 \%$ for the first 10 days, then humidity was gradually reduced for the remainder of the acclimatization period (14 to 18 days). Plants were transplanted to $1000-\mathrm{cm}^{3}$ plastic pots containing a medium of 1 soil : 1 peat : 1 perlite (by volume), and thereafter were maintained on a greenhouse bench under natural photoperiods with day/night cycles of $22 / 18 \pm$ 5C and biweekly applications of $250 \mathrm{ppm} \mathrm{N}$ from a $20 \mathrm{~N}-8.7 \mathrm{P}-16.6 \mathrm{~K}$ water soluble fertilizer (Peters Fertilizer Products, W.R. Grace, Fogelsville, Pa.).

Procedures herein provide a means to clonally reproduce a selected, male genotype of Kentucky coffee tree from a superior, mature specimen. The method may provide a foundation for development of generalizable micropropagation procedures for other mature selections of the species.

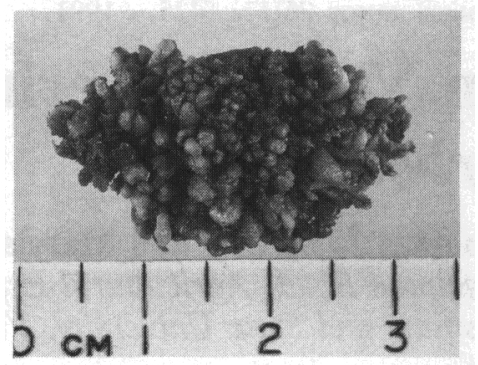

Fig. 1. Multiple shoot buds induced on axillary bud explants of Kentucky coffeetree on a medium containing $36 \mu \mathrm{MBA}$ and $5 \mu \mathrm{M} \mathrm{IBA}$.

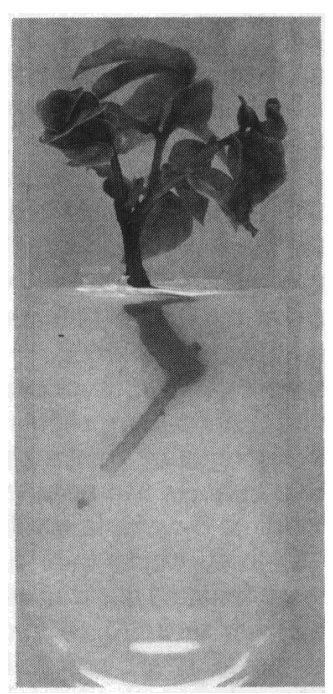

Fig. 2. Plantlet of Kentucky coffeetree rooted on MS medium containing $7.5 \mu \mathrm{M}$ IBA.

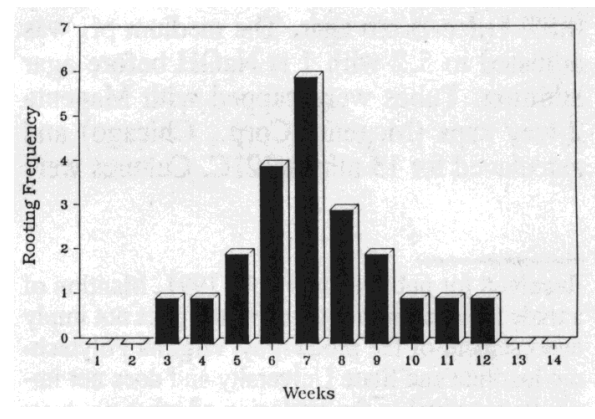

Fig. 3. Frequency of root development on microshoots of Kentucky coffeetree after various durations in root induction medium with $7.5 \mu \mathrm{M}$ IBA, $N=100$. Rooting frequency $=$ mean number of microshoots exhibiting initial root production in a given week from-a sample of 100 microshoots. About $22 \%$ rooting was achieved after 12 weeks.

\section{Literature Cited}

Dirr, M.A. and C.W. Heuser, Jr. 1987. The reference manual of woody plant propagation: From seed to tissue culture. Varsity Press, Athens, $\mathrm{Ga}$.

Geneve, R.L., S.T. Kester, and S. El-Shall. 1990. In vitro shoot initiation in Kentucky coffeetree. HortScience 25:578.

Murashige, T. and F. Skoog. 1962. A revised medium jar rapid growth and bioassays with tobacco tissue cultures. Physiol. Plant. 15:473497. 